Info Artikel Diterima Januari 2021

Disetujui Maret 2021

Dipublikasikan April 2021

\title{
ANALISIS KETAHANAN PANGAN RUMAH TANGGA PETANI BAWANG MERAH (Allium cepa L.) DI KECAMATAN MIJEN KABUPATEN DEMAK
}

\section{FOOD SECURITY ANALYSIS OF SHALLOT (Allium cepa L.) FARMERS HOUSEHOLD IN MIJEN DISTRICT DEMAK REGENCY}

\author{
Inayah Rahmawati Putri Utami, Sri Wahyuningsih, \\ Shofia Nur Awami, Renan Subantoro
}

\author{
Program Studi Agribisnis \\ Fakultas Pertanian Universitas Wahid Hasyim Semarang
}

Email: inayahp97@gmail.com

\begin{abstract}
This study aims to determine the consumption patterns of shallots farmers in the Pasir Village, determine the level of energy and protein adequacy of the household of the shallots farmers in the MijenVillage and determine the level of food security of the shallots farmers in the Pasir Village (Johnsson and Toole model). Methods of data analysis were carried out using percentages of food expenditure, levels of energy and protein consumption, and cross indicators of food security levels. Sampling was done by purposive sampling method by dividing the two strata, strata I were 71 farmers and strata II were 33 farmers. The results of this study indicate that the percentage of food expenditure (PF) for strata I farmers is higher at $53.53 \%$ than strata II farmers at $40.15 \%$. Shallot farmers in Pasir Village have been able to meet the energy and protein needs for household members, but have not yet reached the recommended AKE rate for WNPG XI in 2018 which is $2100 \mathrm{kcal} /$ person / day. The food security status of strata I and II shallod farmers in Pasir Village, Mijen District, Demak Regency is classified in the category of food security, namely the proportion of food expenditure <60while the level of energy consumption $>80 \%$.

Keywords: Consumption Pattern, Shallot, Energy, Protein.
\end{abstract}

\begin{abstract}
ABSTRAK
Penelitian ini bertujuan untuk mengetahui pola konsumsi rumah tangga petani bawang merah di Kecamatan Mijen, tingkat kecukupan energi dan protein rumah tangga petani bawang merah Kecamatan Mijen, serta mengetahui tingkat ketahanan pangan rumah tangga petani bawang merah di Kecamatan Mijen. Metode analisis data dilakukan dengan menggunakan persentase pengeluaran pangan, tingkat konsumsi energi dan protein, dan indikator silang tingkat ketahanan pangan (model Johnsson and Toole). Pengambilan sampel yang dilakukan dengan metode purposive sampling dengan jumlah responden 33 petani. Hasil penelitian ini nilai persentase pengeluaran pangan $(\mathrm{PF})$ yaitu sebesar $40,15 \%$. Rumah tangga di daerah penelitian
\end{abstract}


sudah mampu memenuhi kebutuhan energi dan protein untuk anggota rumah tangga, namun belum mencapai pada angka anjuran AKE pada WNPG XI Tahun 2018 yaitu $2.100 \mathrm{kkal} /$ orang/hari. Status ketahanan pangan rumah tangga petani bawang merah di Kecamatan Mijen Kabupaten Demak tergolong dalam kategori tahan pangan, yaitu proporsi pengeluaran pangan $<60 \%$ sedangkan tingkat konsumsi energinya $>80 \%$.

\section{Kata Kunci : Ketahanan Pangan, Bawang Merah, Energi, Protein.}

\section{PENDAHULUAN}

Pengertian dari pangan perlu dipahami terlebih dahulu, menurut tim Dewan Ketahanan Pangan Jawa Tenggah tahun 2006, pangan adalah segala sesuatu yang berasal dari sumber hayati dan air, baik yang diolah maupun tidak diolah yang diperuntukkan sebagai makanan atau minuman bagi konsumsi manusia termasuk bahan tambahan pangan, bahan baku pangan dan bahan lain yang digunakan dalam proses penyiapan, pengolahan dan atau pembuatan makanan atau minuman. Sedangkan pengertian ketahanan pangan menurut UU No.7/1996) adalah kondisi terpenuhinya pangan bagi rumah tangga yang tercermin dari tersedianya pangan yang cukup, baik jumlah maupun mutunya, aman, merata dan terjangkau.

Konsep ketahanan pangan (food security) lebih luas dibandingkan dengan konsep swasembada pangan, yang hanya berorientasi pada aspek fisik kecukupan produksi bahan pangan. Ketahanan pangan harus mencakup faktor ketersediaan, distribusi, dan konsumsi. Faktor ketersediaan pangan berfungsi menjamin pasokan pangan untuk memenuhi kebutuhan seluruh penduduk, baik dari segi kuantitas, kualitas, keragaman dan keamanannya (Prabowo, 2010). Beberapa ahli sepakat bahwa ketahanan pangan minimal mengandung dua unsur pokok, yaitu "ketersediaan pangan" dan "aksesibilitas masyarakat" terhadap bahan pangan tersebut. Salah satu dari unsur diatas tidak terpenuhi, maka suatu negara belum dapat dikatakan mempunyai ketahanan pangan yang baik. Walaupun pangan tersedia cukup di tingkat nasional dan regional, tetapi jika akses individu untuk memenuhi kebutuhan pangannya tidak merata, maka ketahanan pangan masih dikatakan rapuh (Dewan Ketahanan Pangan Jakarta, 2006).

Kualitas dan kuantitas konsumsi pangan oleh setiap individu akan mempengaruhi status ketahanan pangan individu tersebut. Ketersediaan pangan dalam rumahtangga merupakan salah satu indikator keberhasilan ketahanan pangan dalam rumah tangga itu sendiri. Terwujudnya ketahanan pangan sampai pada tingkat rumahtangga berarti mampu memperoleh pangan yang cukup jumlah, mutu, dan beragam untuk memenuhi $\mathrm{k}$ ebutuhan pangan dan gizi. Cukup disini berarti tidak hanya beras tetapi pangan non beras yang berasal dari tanaman, ternak, dan ikan untuk memenuhi kebutuhan atas karbohidrat, lemak, protein, vitamin, dan mineral yang bermanfaat bagi pertumbuhan Kesehatan manusia (Dewan Ketahanan Pangan Jakarta, 2006)

Tercukupinya kebutuhan pangan dapat diindikasi dari pemenuhan kebutuhan energi dan protein. Zat - zat gizi yang lain akan terpenuhi jika konsumsi energi dan 
protein sudah terpenuhi sesuai angka kecukupan gizi (AKG). Angka kecukupan gizi seseorang akan berbeda sesuai jenis kelamin dan umur. Menurut penelitian Agustina, dkk (2015) di Kecamatan Indrapuri Kabupaten Aceh Besar sebanyak 62, 19 \% masyarakat berada pada kategori defisit gizi atau kurang dari $70 \%$ angka kecukupan gizi yang dianjurkan.

Kecamatan Mijen merupakan tempat produksi terbesar untuk tanaman bawang merah khususnya di Kabupaten Demak. Sebagian besar penduduknya bekerja pada sektor pertanian terutama pada petani bawang merah. Hasil panen bawang merah di kecamatan tersebut mampu memenuhi kebutuhan bawang merah di kabupaten tetangga seperti Kabupaten Pati, Kudus, Jepara, Rembang dan kota lainnya.

Ketersediaan dan ketahanan pangan merupakan salah satu masalah yang sangat krusial di Indonesia. Karenanya salah satu indikator utama bagi keberhasilan pembangunan dan penyelenggaraan pemerintah sering diukur dan dikaitkan dengan kemampuan pemerintah dalam menyediakan pangan bagi rakyatnya. Suatu daerah belum dikatakan mandiri jika masih terdapat masalah ketahanan pangan yaitu tercermin dari belum adanya peningkatan pendapatan dan kesejahteraan (Purwaningsih., dkk, 2008)

Berdasarkan hal tersebut di atas maka dapat disusun rumusan masalah sebagai berikut: (1) bagaimana pola konsumsi rumah tangga petani bawang merah di Kecamatan Mijen Kabupaten Demak, (2) berapa tingkat kecukupan energi dan protein rumah tangga petani bawang merah di Kecamatan Mijen Kabupaten Demak, (3) bagaimana tingkat ketahanan pangan rumah tangga petani bawang merah di Kecamatan Mijen Kabupaten Demak.

\section{BAHAN DAN METODE}

Metode yang digunakan dalam penelitian ini adalah metode deskriptif analisis, yaitu metode dalam meneliti status kelompok manusia, suatu objek, suatu kondisi dan pemikiran, ataupun kelas peristiwa pada masa sekarang. Tujuan penelitian ini adalah membuat deskripsi, gambaran, atau lukisan secara sistematis, faktual dan akurat mengenai fakta - fakta, sifat - sifat serta hubungan antar fenomena yang diselidiki (Rianse, 2012). Metode pengambilan sampel responden dilakukan dengan cara purposive sampling yaitu teknik pengambilan sampel dengan menentukan kriteria- kriteria tertentu (Sugiyono, 2015). Penelitian ini melibatkan 33 petani bawang merah yang masih aktif membudidayakan bawang merah dengan luas lahan lebih dari satu hektar. Pengambilan data lapangan dilakukan pada bulan Februari 2020.

\section{Teknik Analisis Data}

\section{Analisis Pangsa Pengeluaran Pangan}

Analisis yang digunakan untuk menghitung apakah pangsa pengeluaran pangan lebih besar dari pangsa pengeluaran non pangan rumah tangga, dengan menggunakan analisis pangsa pengeluaran pangan sebagai berikut: 


$$
\mathbf{P F}=\frac{\mathbf{P P}}{\mathrm{TP}} \times 100 \%
$$

Keterangan:

$\mathrm{PF}$ : Pangsa pengeluaran pangan (\%)

PP : Pengeluaran untuk belanja pangan (Rp/bulan)

$\mathrm{TP}$ : Pangsa pengeluaran non pangan ( $\mathrm{Rp} / \mathrm{bulan})$

\section{Analisis Tingkat Konsumsi Energi dan Protein Rumah Tangga}

Konsumsi energi dan protein rumah tangga dihitung menggunakan rumus sebagai berikut:

$$
G i j=\frac{B P j}{100} \times \frac{B d d j}{100} \times K G i j
$$

Keterangan:

Gij : Jumlah energi atau protein yang dikonsumsi dari pangan $\mathrm{j}$ (energi dalam satuan kilokalori dan protein dalam satuan gram)

$\mathrm{BPj} \quad$ : Berat pangan $\mathrm{j}$ yang dikonsumsi (gram)

Bddj $\quad$ : Bagian yang dapat dimakan dari 100 gram pangan $\mathrm{j}(\%)$

Khij : Kandungan energi atau protein per 100 gram pangan $\mathrm{j}$ yang dikonsumsi (energi dalam satuan kilokalori dan protein dalam satuan gram) (Suyatno, 2010).

Daftar perhitungan rata - rata Angka Kecukupan Energi (AKE) dan Angka Kecukupan Protein berdasarkan umur dan jenis kelamin menggunakan standar WNPG IX tahun 2018. Perbandingan antara konsumsi zat gizi dengan angka kecukupan gizi yang dianjurkan disebut sebagai Tingkat Konsumsi Gizi (TKG). Berdasarkan Buku Pedoman Petugas Gizi Puskesmas, Depkes RI (1990) TKG diklasifikasikan berdasarkan Depkes (1990) dalam Supriasa (2001), yaitu :
1) Baik $\quad:$ TKG $\geq 100 \%$ AKG
2) Sedang : TKG $80-99 \%$ AKG
3) Kurang : TKG $70-80 \%$ AKG
4) Defisit $\quad: T K G \leq 70 \%$ AKG

Analisis Ketahanan Pangan Rumah Tangga

\begin{tabular}{|c|c|c|}
\hline Konsumsi Energi & Pangsa Pengeluara & ngan \\
\hline & $\begin{array}{l}\text { Rendah } \\
(<60 \% \text { pengeluaran } \\
\text { total })\end{array}$ & $\begin{array}{l}\text { Tinggi } \\
(\geq 60 \% \\
\text { total) }\end{array}$ \\
\hline $\begin{array}{l}\text { Cukup } \\
(>80 \% \text { kecukupan energi) }\end{array}$ & 1. Tahan Pangan & 2. Rentan Pangan \\
\hline $\begin{array}{l}\text { Kurang } \\
\text { ( } \leq 80 \% \text { kecukupan energi) }\end{array}$ & 3. Kurang Pangan & 3. Rawan Pangan \\
\hline
\end{tabular}

Tabel 1. Kategori Rumah Tangga Berdasarkan Indikator Ketahanan Pangan

Sumber: Johnsson and Toole, 1991 dalam Maxwel dan Frankenberger, 2000. 


\section{HASIL DAN PEMBAHASAN}

\section{Karakteristik Responden Petani Bawang Merah}

Karakteristik responden merupakan profil terhadap obyek penelitian yang memberikan gambaran secara umum mengenai keadaan responden yang meliputi data identitas responden dan anggota keluarga responden. Responden dari penelitian ini adalah para petani yang masih aktif menanam bawang merah. Responden yang menjadi sampel berjumlah 33. Adapun data karakteristik responden berdasarkan umur, pendidikan dan jumlah anggota keluarga dapat dilihat pada Tabel 2.

Tabel 2. Data Karakteristik Responden Berdasarkan Umur, pendidikan dan Jumlah Anggota Keluarga

\begin{tabular}{|c|c|c|c|c|}
\hline No. & Karakteristik & Keterangan & Jumlah & Persentase $(\%)$ \\
\hline \multirow[t]{3}{*}{1} & \multirow[t]{3}{*}{$\begin{array}{l}\text { Umur } \\
\text { (Tahun) }\end{array}$} & $25-40$ & 2 & 6,07 \\
\hline & & $41-50$ & 6 & 18,18 \\
\hline & & $>50$ & 25 & 75,75 \\
\hline \multirow[t]{3}{*}{2} & \multirow[t]{3}{*}{ Pendidikan } & SD & 11 & 33,33 \\
\hline & & SMP & 18 & 54,55 \\
\hline & & SMA & 4 & 12,12 \\
\hline \multirow[t]{5}{*}{3} & \multirow{4}{*}{$\begin{array}{l}\text { Jumlah Anggota } \\
\text { Keluarga }\end{array}$} & 2 & 2 & 6,06 \\
\hline & & 3 & 5 & 15,15 \\
\hline & & 4 & 20 & 60,60 \\
\hline & & $>5$ & 6 & 18,19 \\
\hline & Jumlah Responden & & 33 & 100 \\
\hline
\end{tabular}

Sumber: Analisis Data Primer, 2020.

Berdasarkan sebaran umur responden dapat diketahui bahwa kelompok umur terbanyak adalah kelompok lebih dari 50 tahun, usia tersebut tergolong usia yang produktif (15-64) sehingga dapat mengerjakan pekerjaan usaha taninya dengan maksimal untuk memenuhi kebutuhan rumah tangganya. Tingkat pendidikan kepala keluarga paling banyak adalah SMP. Tingkat pendidikan ini berpengaruh terhadap pengetahuan kecukupan gizi rumah tangga dan keputusan konsumsi rumah tangga. Semakin tinggi pendidikan maka akan semakin tinggi pula kemampuan dalam hal keputusan konsumsi rumah tangga terutama dalam pemenuhan gizi. Jika dilihat dari rata-rata anggota rumah tangga yaitu petani memiliki anggota keluarga 4 orang. Secara umum, besar kecilnya jumlah anggota rumah tangga akan mempengaruhi jumlah pengeluaran konsumsi rumah tangga, karena dengan bertambahnya jumlah anggota rumah tangga kebutuhan rumah tangga akan meningkat. 


\section{Pengeluaran Rumah Tangga Petani}

Pengeluaran rumah tangga adalah berbagai pengeluaran konsumsi akhir rumah tangga atas barang dan jasa untuk memenuhi kebutuhan individu ataupun kelompok secara langsung. Pengeluaran rumah tangga mencakup pembelian untuk makanan dan bukan makanan (barang dan jasa). Dalam penelitian ini pengeluaran rumah tangga merupakan pengeluaran total yang dikeluarkan suatu rumah tangga selama satu bulan. Pengeluaran total rumah tangga dapat diketahui dengan menghitung jumlah rupiah yang dikeluarkan oleh suatu rumah tangga selama sebulan, baik itu untuk keperluan sehari-hari maupun untuk keperluan rumah tangga lainnya. Pengeluaran rumahtangga petani bawang merah di Desa Pasir terdiri atas pengeluaran pangan dan pengeluaran nonpangan. Pengeluaran pangan dan non pangan setiap rumah tangga bervariasi.

Tabel 3. Pengeluaran Pangan Rumah Tangga Petani Bawang Merah Desa Pasir Kecamatan Mijen Kabupaten Demak

\begin{tabular}{llll}
\hline No. & Jenis Makanan & $\begin{array}{l}\text { Pengeluaran } \\
(\text { Rp/bulan) }\end{array}$ & Persentase (\%) \\
\hline 1 & Padi-padian & 186.364 & 12,59 \\
2 & Umbi-umbian & 26.197 & 1,77 \\
3 & Ikan & 174.318 & 11,77 \\
4 & Daging & 115.667 & 7,81 \\
5 & Telur dan susu & 137.727 & 9,30 \\
6 & Sayur-sayuran & 167.121 & 11,29 \\
7 & Kacang-kacangan & 71.617 & 4,84 \\
8 & Buah-buahan & 58.485 & 3,95 \\
9 & Minyak dan lemak & 79.900 & 5,40 \\
10 & Bahan minuman & 120.000 & 8,10 \\
11 & Bumbu-bumbuan & 92.242 & 6,32 \\
12 & Konsumsi lain & 87.121 & 5,88 \\
13. & Makanan dan minuman jadi & 161.818 & 10,93 \\
\hline \multicolumn{4}{l}{ Sumber: Analisis Data Primer, 2020. } \\
\hline
\end{tabular}

Sumber : Analisis Data Primer, 2020.

Berdasarkan Tabel 3. dapat diketahui bahwa rata-rata pengeluaran pangan rumah tangga petani bawang merah Desa Pasir Kecamatan Mijen Kabupaten Demak yaitu sebesar Rp 1.480.627 pada setiap bulan. Pengeluaran pangan terbanyak yaitu untuk padi-padian, padi - padian ini berupa beras yang merupakan konsumsi atau sumber energi utama rumah tangga. Sementara berdasarkan Tabel 4. rata-rata pengeluaran non pangan rumah tangga petani bawang merah di Desa Pasir Kecamatan Mijen Kabupaten Demak pada bulan Februari 2020 adalah sebesar Rp 2.737.002 Pengeluaran non pangan terbanyak masyarakat Desa Pasir adalah untuk keperluan pendidikan seperti SPP, uang saku, uang kos, seragam dan buku yaitu 
sebesar Rp 1.520.966. Pengeluaran non pangan paling kecil adalah pajak. Keperluan pajak rata-rata rumah tangga petani bawang merah hanya $3,11 \%$. Pengeluaran pajak meliputi pajak bumi dan bangunan (PBB), pajak motor/mobil, dan lainnya.

Tabel 4. Rata-Rata Pengeluaran Non Pangan Rumah Tangga Petani Bawang Merah di Desa Pasir Kecamatan Mijen Kabupaten Demak

\begin{tabular}{llll}
\hline \multirow{2}{*}{ No. } & Pengeluaran Non & Pengeluaran (Rp/bulan) & Persentase (\%) \\
\hline 1 & Listrik dan BBM & 401.803 & 14,68 \\
2 & Rokok & 308.258 & 11,26 \\
3 & Pendidikan & 1.520 .966 & 55,57 \\
4 & Kegiatan Sosial & 159.242 & 5,81 \\
5 & Keperluan sehari - hari & 144.788 & 5,29 \\
6 & Komunikasi & 129.697 & 4,73 \\
7 & Pajak & 85.290 & 3,11 \\
8 & Pakaian & 107.344 & 3,92 \\
9 & Kesehatan & 85.909 & 3,13 \\
\hline & Jumlah & 2.737 .002 & 100 \\
\hline
\end{tabular}

Sumber : Analisis Data Primer, 2020.

\section{Pangsa Pengeluaran Pangan}

Pangsa pengeluaran pangan yang merupakan besarnya jumlah pengeluaran rumah tangga untuk belanja pangan maupun non pangan. Pangsa pengeluaran pangan rumah tangga petani bawang merah Kecamatan Mijen Kabupaten Demak dapat dilihat pada Tabel 5 .

Tabel 5. Jumlah Pengeluaran Pangan dan Non Pangan Rumah Tangga Petani Bawang Merah Di Desa Pasir Kecamatan Mijen Kabupaten Demak

\begin{tabular}{llll}
\hline Pengeluaran & $\begin{array}{l}\text { Rata }- \text { rata } \\
(\text { Rp/bulan) }\end{array}$ & $\begin{array}{l}\text { Persentase } \\
(\%)\end{array}$ & Pangsa Pengeluaran Pangan (\%) \\
\hline Pangan & 1.480 .627 & 35,11 & \\
Non Pangan & 2.737 .002 & 64,80 & 40,15 \\
\hline Total & 2.968 .880 & 100 & \\
\hline
\end{tabular}

Sumber : Analisis Data Primer, 2020.

Berdasarkan Tabel 5. dapat diketahui bahwa rata-rata total pengeluaran rumah tangga petani bawang merah di Kecamatan Mijen sebesar Rp 2.968.880 pada setiap bulan. Rata pengeluaran pangan rumah tangga petani bawang merah di Kecamatan Mijen sebesar Rp 1.480.627/bulan atau 35,11\%, sedangkan untuk rata rata pengeluaran non pangan sebesar Rp 2.737.002/bulan atau 64,80\%.Berdasarkan hasil penelitian ini dapat diketahui bahwa rumah tangga petani bawang merah 
memiliki kesejahteraan yang tinggi dilihat dari proporsi pengeluaran non pangan yaitu 50,39 pada setiap bulannya.

Selaras dengan penelitian Faizah, dkk (2018) yang menujukkan pangsa pengeluaran pangan rumah tangga nelayan di Kabupaten Jepara, sebesar 48,20\%, sedangkan pangsa pengeluaran non pangan sebesar $51,80 \%$, artinya pangsa pengeluaran pangan kurang dari $60 \%$ pangsa pengeluaran non pangan yang menunjukkan bahwa tingkat kesejahteraan rumah tangga nelayan tinggi atau tahan pangan. Sependapat Ariniani dan Purwantini (2014) yang menyatakan bahwa semakin tinggi pangsa pengeluaran pangan berarti semakin kurang kesejahteraan rumah tangga tersebut. Sebaliknya semakin rendah pangsa pengeluaran pangan maka rumah tangga tersebut semakin sejahtera.

\section{Konsumsi Pangan Rumah Tangga}

Konsumsi pangan rumah tangga petani dapat dilihat dari kuantitas dan kualitas konsumsi pangan. Kualitas pangan menunjukkan adanya gizi yang dibutuhkan oleh tubuh sedangkan kuantitas pangan menunjukkan jumlah gizi dalam suatu bahan pangan. Konsumsi pangan dapat dinilai dari konsumsi gizi yaitu energi dan protein. Konsumsi yang dihitung tidak hanya bahan pokok tetapi bahan pangan lainnya seperti buah-buahan dan sebagainya. Struktur konsumsi pangan baik konsumsi energi atau protein rumah tangga petani bawang merah di Kecamatan Mijen dapat dilihat pada Tabel 6 dan 7 .

Tabel 6. Struktur Konsumsi Energi Petani Bawang Merah Desa Pasir

\begin{tabular}{llll}
\hline No. & Jenis Makanan & Jumlah Energi (Kkal/Org/Hr) & Persentase (\%) \\
\hline & & & \\
1. & Padi-padian & 557,90 & 28,67 \\
2. & Umbi-umbian & 132,99 & 6,83 \\
3. & Ikan & 88,13 & 4,53 \\
4. & Daging & 335,50 & 17,24 \\
5. & Telur dan susu & 100,97 & 5,19 \\
6. & Sayur-sayuran & 71,38 & 3,67 \\
7. & Kacang-kacangan & 66,66 & 3,43 \\
8. & Buah-buahan & 58,96 & 3,03 \\
9. & Minyak dan lemak & 159,97 & 8,22 \\
10. & Bahan minuman & 68,17 & 3,50 \\
11. & Bumbu-bumbuan & 21,26 & 1,09 \\
12. & Konsumsi lain & 284,06 & 14,60 \\
\hline & Jumlah & $1.945,94$ & 100 \\
\hline
\end{tabular}

Sumber: Analisis Data Primer, 2020. 
Dari Tabel 6 dapat diketahui bahwa konsumsi energi terbesar pada rumah tangga petani bawang merah di Kecamatan Mijen yaitu pada kelompok padi-padian sebesar 557,90 kkal/orang/hari atau 28,67 \%. Hal ini dikarenakan kelompok padipadian memiliki kandungan energi yang tinggi. Sedangkan konsumsi energi terkecil pada rumah tangga petani bawang merah adalah kelompok bumbu-bumbuan yaitu sebesar 21,26 kkal/orang/hari.

Tabel 7. Struktur Konsumsi Protein Petani Bawang Merah Desa Pasir

\begin{tabular}{clll}
\hline No. & \multicolumn{1}{c}{ Jenis Makanan } & $\begin{array}{l}\text { Protein } \\
(\mathrm{gr} / \mathrm{org} / \mathrm{hr})\end{array}$ & $\%$ \\
\hline 1. & Padi-padian & 11,73 & 15,94 \\
2. & Umbi-umbian & 0,68 & 0,92 \\
3. & Ikan & 14,46 & 19,65 \\
4. & Daging & 19,99 & 27,19 \\
5. & Telur dan susu & 6,84 & 9,30 \\
6. & Sayur-sayuran & 4,80 & 6,52 \\
7. & Kacang-kacangan & 5,41 & 7,36 \\
8. & Buah-buahan & 0,52 & 0,71 \\
9. & Minyak dan lemak & 0,62 & 0,84 \\
10. & Bahan minuman & 0,16 & 0,22 \\
11. & Bumbu-bumbuan & 1,90 & 2,60 \\
12. & Konsumsi lain & 6,43 & 8,74 \\
\hline & Jumlah & 73,54 & 100 \\
\hline
\end{tabular}

Sumber : Analisis Data Primer, 2020.

Berdasarkan Tabel 7. dapat diketahui bahwa rata-rata konsumsi protein rumah tangga petani bawang merah di Desa Pasir yaitu sebesar 73,54 gram/orang/hari. Jumlah konsumsi protein terbesar adalah kelompok daging yaitu 19,99 gram/orang/hari atau 27,19\%. Daging yang dikonsumsi biasanya berupa daging ayam broiler. Sedangkan untuk konsumsi protein terkecil adalah pada kelompok bahan minuman, yaitu 0,17 gram/orang/hari $(0,25 \%)$. Kelompok bahan minuman yang dikonsumsi yaitu teh dan kopi. Teh dan kopi tidak memiliki kandungan protein, sehingga jumlah protein dalam kelompok bahan minuman yang dikonsumsi oleh rumah tangga petani bawang merah tergolong kecil.

\section{Tingkat Konsumsi Energi dan Protein}

Konsumsi energi dan protein dapat dilihat dari pola konsumsi pangan. Konsumsi pangan rumah tangga merupakan kebutuhan makanan dan minuman seluruh anggota rumah tangga terhadap pangan yang bertujuan untuk memenuhi kebutuhan. Rata-rata konsumsi energi dan protein rumah tangga petani bawang merah di Desa Pasir Kecamatan Mijen Kabupaten Demak dapat dilihat pada Tabel 8. 
Tabel 8. Rata-Rata Konsumsi Energi Dan Protein Rumah Tangga Petani Bawang Merah di Desa Pasir Kecamatan Mijen Kabupaten Demak

\begin{tabular}{llll}
\hline Kandungan Gizi & Konsumsi & AKG Anjuran & TKG (\%) \\
\hline Energi (kkal/orang/hari) & 1945,94 & 2225,23 & 87,44 \\
Protein (gram/orang/hari) & 73,54 & 62,24 & 118,15 \\
\hline
\end{tabular}

Sumber : Analisis Data Primer, 2020.

Berdasarkan hasil penelitian rata-rata konsumsi energi rumah tangga petani bawang merah adalah 1945, $94 \mathrm{kkal} /$ orang/hari dengan AKG anjuran 2.225,23 $\mathrm{kkal} /$ orang/hari. Sedangkan rata-rata konsumsi protein sebesar 73,54 gram/orang/hari dengan AKG 62,24 gram/orang/hari. Berdasarkan nilai TKG energi rumah tangga petani di daerah penelitian sudah tergolong sedang (80-99\%). Hal ini artinya rumah tangga petani di daerah penelitian telah mampu mencukupi kebutuhan energinya. Persentase TKG protein pada rumah tangga di daerah penelitian sudah tergolong baik karena sudah mencapai $>100 \%$ dari AKG yaitu 118,15\%. Tingkat konsumsi energi dan protein diperoleh dari makanan dan minuman yang dikonsumsi setiap hari. Penyumbang terbesar energi yaitu pada kelompok pangan padi-padian yang merupakan sumber karbohidrat. Sedangkan untuk protein diperoleh dari konsumsi pangan kelompok daging yang berupa daging ayam. Selain itu protein juga diperoleh dari kelompok kacang-kacangan seperti tahu dan tempe yang merupakan protein nabati yang sering dikonsumsi oleh rumah tangga petani bawang merah di daerah penelitian. Kebutuhan pangan di daerah penelitian biasanya diperoleh dari pasar desa dan warung - warung terdekat.

Sementara hasil penelitian Ni'mah, dkk (2020) yang berjudul Analisis Pola Konsumsi Rumah Tangga Perani Ganyong Di Kecamatan Dawe Kabupaten Kudus, menunjukan bahwa angka kecukupan energi pada masyarakat adalah 1947,73 $\mathrm{kkal} /$ orang/hari, dan angka kecukupan protein 59,04 gram/orang/hari. Apabila hasil penelitian rumah tangga petani bawang merah dan rumah tangga petani ganyong dibandingkan dari segi konsumsi energi dan protein rumah tangga maka rumah tangga petani bawang merah memiliki tingkat konsumsi pangan yang lebih rendah daripada konsumi rumah tangga petani ganyong.

Berdasarkan Tabel 8. menunjukkan bahwa Angka Kecukupan Energi (AKE) tingkat rumah tangga petani bawang merah di daerah penenlitian sudah terpenuhi energinya. Sebanyak 33 rumah tangga petani bawang merah pada kategori cukup yang berarti kecukupan energinya lebih dari $2.100 \mathrm{kkal} /$ orang/hari sesuai dengan syarat kecukupan pangan tingkat rumah tangga oleh Widyakarya Nasional Pangan dan Gizi (WNPG) X Tahun 2018 yaitu 2.100 kkal/orang/hari.

\section{Ketahanan Pangan}

Cukup atau tidaknya pangan akan mempengaruhi gizi pangan. Oleh karena itu, untuk mengetahui ketahanan pangan rumah tangga diperlukan klasifikasi silang antara proporsi pengeluaran pangan dan tingkat konsumsi energi rumah tangga. 
Berikut sebaran ketahanan pangan rumah tangga petani bawang merah di Kecamatan Mijen.

Berdasarkan Tabel 10 diketahui bahwa status ketahanan pangan rumah tangga petani bawang merah di Kecamatan Mijen Kabupaten Demak tergolong dalam kategori tahan pangan, yaitu proporsi pengeluaran pangan $<60 \%$ sedangkan tingkat konsumsi energinya $>80 \%$. Terdapat 26rumah tangga petani bawang yang tergolong dalam kategori tahan pangan. Hal ini berarti sebagian besar rumah tangga petani bawang merah di Kecamatan Mijen telah mampu memenuhi kebutuhan pangan rumah tangga, gizi keluarga yang sudah tercukupi dan akses pangan yang mudah dijangkau.

Tabel 10. Analisis Tingkat Ketahanan Pangan Rumah Tangga Petani Bawang Merah Di Desa Pasir Kecamatan Mijen Kabupaten Demak

\begin{tabular}{lll}
\hline Ketahanan Pangan & Jumlah (Orang) & Persentase $(\%)$ \\
\hline Tahan Pangan & 26 & 78,78 \\
Rentan Pangan & 0 & 0 \\
Kurang Pangan & 7 & 21,22 \\
Rawan Pangan & 0 & 0 \\
\hline Jumlah & 71 & 100 \\
\hline
\end{tabular}

Sumber : Data Primer, 2020.

Status ketahanan pangan kategori kurang pangan yaitu kondisi dimana proposi pengeluaran pangan rendah $<60 \%$ dan tingkat konsumsi energi kurang. Terdapat 21,22\% rumah tangga petani bawang merah dalam kategori kurang pangan. Menurut hasil penelitian ini, rumah tangga yang tergolong dalam kategori kurang pangan disebabkan oleh besarnya biaya pengeluaran non pangan berupa biaya pendidikan. Banyaknya anak usia sekolah dan anak yang dibiayai untuk pendidikan yang lebih tinggi membuat pengeluaran non pangan rumah tangga lebih tinggi. Pada daerah penelitian, biaya pendidikan mendominasi paling tinggi daripada biaya yang lainnya. Tingkat konsumsi energi yang rendah disebbakan oleh kurangnya pengetahuan tentang gizi makanan sehingga banyak rumah tangga yang belum mencapai tingkat konsumsi energi yang baik. Oleh karena itu dibutuhkan peran ibu rumah tangga yang mengatur menu makanan menjadi lebih bervariasi dan bergizi tinggi. Hal ini selaras dengan hasil penelitian Awami (2015) yang menunjukkan distribusi rumah tangga pengolah gula aren di Kabupaten Kendal berada pada kategori tahan pangan dan kurang pangan.

\section{KESIMPULAN DAN SARAN}

Berdasarkan penelitian yang dilakukan di Kecamatan Mijen Kabupaten Demak mengenai pola konsumsi rumah tangga petani bawang merah dapat disimpulkan proporsi pengeluaran rumah tangga petani yang diproksi dari pengeluaran pangan dan non pangan di Kecamatan Mijen yaitu rata-rata pengeluaran 
pangan Rp 1.480.627/bulan dan rata - rata pengeluaran non pangan sebesar Rp 2.737.002/bulan. Rata-rata konsumsi energi rumah tangga petani bawang merah yaitu 1945,94 kkal/orang/hari dan rata - rata konsumsi protein yaitu 73,54 gram/orang/hari. Kondisi ketahanan pangan rumah tangga petani bawang merah berada pada kategori tahan pangan, dan sisanya berada pada kategori kurang pangan.

Saran yang diberikan yaitu diperlukan adanya sosialisasi terkait tingkat kecukupan energi dan protein setiap rumah tangga dari pihak terkait sehingga harapannya semua masyarakat berada pada kategori tahan pangan dan diperlukan adanya penelitian lanjutan tentang faktor - faktor yang mempengaruhi tingkat ketahanan pangan rumah tangga di Kecamatan Mijen.

\section{DAFTAR PUSTAKA}

Agustina, dkk. (2015). Analisis Ketahanan Pangan Rumah Tangga Berdasarkan Proporsi Pengeluaran Pangan dan Konsumsi Energi. Agrisep Vol. 16 No.1. Universitas Syah Kula. Banda Aceh.

Ariani dan Purwantini. (2014). Pola Konsumsi Pangan Rumah Tangga Petani Karet Kecamatan Mandiangian Kabupaten Sorolangun. Sosio Ekonomika Bisnis, 17(2). Fakultas Pertanian Universitas Jambi. Jambi.

Awami, Shofia Nur Dan Subekti, Endah. (2015). Pola Konsumsi Pangan Dan Permintaan Beras Oleh Rumah Tangga Pengolah Gula Merah Aren Di Kabupaten Kendal. Prosiding SNST Ke-6 Tahun 2015. Fakultas Teknik Universitas Wahid Hasyim. Semarang.

Dewan Ketahanan Pangan Propinsi Jawa Tengah, 2006. Pedoman Umum Kebijakan Pemantapan Ketahanan Pangan Propinsi Jawa Tengah Tahun 2006. Dewan Ketahanan Pangan Propinsi Jawa Tengah. Semarang.

Dewan Ketahanan Pangan Propinsi Jawa Tengah, 2006. Kebijakan Umum Ketahanan Pangan 2006 - 2009. Dewan Ketahanan Pangan. Jakarta.

Faizah, S N, S. Supardi, S.N. Awami. 2018. Analisis Ketahanan Pangan Rumah Tangga Nelayan di Kecamatan Jepara Kabupaten Jepara. Prosiding Seminar Nasional Fakultas Pertanian UNS. Vol 2. No. 1. Surakarta.

Maxwell dan Frankenberger 2000. Urban Livelihoods and Food and Nutrition Seceurity in Greater accra Ghana. International Food Policy Research Security in Collaboration with Noguchi Memorial Institute For Medical Research World Health Organization. 172 Halaman. 
Purwaningsih, Y., dkk. (2010). Pola Pengeluaran Rumah Tangga Menurut Tingkat Ketahanan Pangan di Propinsi Jawa Tengah. Fakultas Pertanian Universitas Gadjah Mada . Yogyakarta.

Prabowo, R (2010). Kebijakan Pemerintah Dalam Mewujudkan Ketahanan Pangan Di Indonesia. Jurnal Mediagro 6. (2), 2010.Hal: 62 - 73

Rianse, Usman. 2012. Metode Penelitian Sosial dan Ekonomi Teori dan Aplikasi. Bandung. Alfabeta.

Suyatno. 2010. Manajemen Perbekalan ( logistik) Makanan. Bagian Gizi FKM UNDIP. Semarang.

Ni'mah, Lu'lua Ulyn; Awami, Shofia Nur; Supardi, Suprapti; dan Subekti, Endah. (2020). Analisis Pola Konsumsi Pangan Rumah Tangga Petani Ganyong (Canna edulis Ker.) di Desa Japan Kecamatan Dawe Kabupaten Kudus. Jurnal Partner. Jil 25 (2). Hal 1363-1376. Politani Negeri Kupang. Kupang.

Sugiyono. (2015). Metode Penelitian Kuantitatif Kualitatif $R \& B$. Aflabeta. Bandung. Widyakarya Pangan dan Gizi X. (2018). Pemantapan Ketahanan Pangan Perbaikan Gizi Berbasis Kemandirian dan Kearifan Lokal. Jakarta: 20-21 November. 